ISSN 1392-3196 / e-ISSN 2335-8947

Zemdirbyste-Agriculture, vol. 100, No. 4 (2013), p. 377-382

DOI 10.13080/z-a.2013.100.048

\title{
The impact of long-term reduced primary soil tillage on maize (Zea mays L.) productivity
}

\author{
Dovilè AVIŽIENYTĖ, Kęstutis ROMANECKAS, Rita PALIŠKYTÉ, \\ Vaclovas BOGUŽAS, Vytautas PILIPAVIČIUS, Egidijus ŠARAUSKIS, \\ Aida ADAMAVIČIENĖ, Edvardas VAICIUKEVIČIUS \\ Aleksandras Stulginskis University \\ Studentų 11, Akademija, Kaunas distr., Lithuania \\ E-mail: dovilea@manopastas.lt, kestas.romaneckas@asu.lt
}

\begin{abstract}
A long-term field experiment (since 1988) was carried out at the Experimental Station of the Aleksandras Stulginskis University (ASU, 54 $52^{\prime} \mathrm{N}, 23^{\circ} 49^{\prime} \mathrm{E}$ ) in the conditions of transitional maritime-climate. Research data from the 2010-2012 experimental period are presented. The soil of the experimental site is silty light loam Endohypogleyic-Eutric Planosol (PLe-gln-w). Average annual temperature is $6.2^{\circ} \mathrm{C}$. The aim of the experiment was to establish the influence of reduced primary autumn soil tillage on maize productivity. The treatments of the experiment were: 1) conventionally $(22-25 \mathrm{~cm})$ ploughed by a mouldboard plough, 2$)$ shallowly $(12-15 \mathrm{~cm})$ ploughed by a mouldboard plough, 3) deeply $(25-30 \mathrm{~cm})$ tilled by a chisel cultivator, 4) shallowly $(10-12 \mathrm{~cm})$ tilled by a disc harrow, 5) no-till. The experimental results showed that all primary soil tillage methods (except for chiselling) normally had insignificant effect on maize biometric parameters. Deep chiselling had consistent negative influence on the biometric parameters of maize canopy, while no no-till effect was insignificantly positive. Maize crop biometric parameters partially depended on weed infestation at the beginning and the end of maize vegetation. In two out of three experimental years, maize crop density at the beginning and end of vegetation did not differ significantly in differently tilled plots. A relationship was found between the number of annual as well as total number of weeds and crop density at the beginning of vegetation $\left(r=-0.926^{* *}\right.$ and $\left.-0.948^{* *}\right)$. Crop density at the beginning of vegetation had significant positive effect on most maize productivity parameters. Reduced soil tillage from shallow ploughing to no-till had total positive effect on maize productivity in 2011 only because of the lower weed infestation. Relationships were established between weed infestation and maize crop productivity parameters (correlation coefficients from -0.394 to $-0.965^{* *}$ ). Productivity parameters were influenced by biometric parameters too (correlation coefficients from $0.713 * *$ to $0.920^{* *}$ ).
\end{abstract}

Key words: biometric parameters, productivity, soil tillage, Zea mays.

\section{Introduction}

Maize growing is still quite new in the countries of North Europe because of cold subarctic climate conditions and short vegetation period. Marginal area of maize growing could be located up to the North $58^{\circ}$ latitude in Latvia (Gaile, 2012) and $56^{\circ}$ latitude in Lithuania. Due to the availability of new early varieties and novel approach to growing technologies, in Lithuania the area of continuous maize growing for grain increased from 5.4 in 2007 to 10.4 thousand ha in 2011, total grain yield rose from 26.0 to 71.9 thousand $\mathrm{t}$, yield per ha from 4.8 to $7.5 \mathrm{t} \mathrm{ha}^{-1}$, accordingly (Statistics Lithuania, 2005 ) and tended to increase. The main question is how to produce maize grain cheaper because grain drying requires high energy input and increases production costs. One of the resorts is to economize fuel and labour power consumption by reducing soil tillage because it often had insignificant influence on the yield of many crops (Håkansson et al., 1998; Hao et al., 2001). Similar results were obtained in Lithuania too. In minimally tilled soil the yields of many winter or spring cereals and sugar beet were higher or little less than those in deeply ploughed soils (Cesevičius et al., 2005; Romaneckas, 2011). However, some scientists have reported opposite findings (Maikštenienè et al., 2007). The success of soil tillage reduction depended on soil type, plant residue management, sowing and tillage machinery, meteorological conditions, as well as on how long such technologies had been used and other factors. Application of no-till system mostly had negative influence on crop productivity in Lithuania.

Reduced primary soil tillage systems for maize, especially continuous, are not widely investigated in Lithuania. In our previous short-term on-farm scale or stationary precision experiments in the conditions of well-balanced, even mineral fertilization the reduction of soil tillage intensity from deep mouldboard ploughing to shallow stubble disking had insignificant influence on maize productivity parameters (Romaneckas et al., 
2010). World practices showed similar maize yields both in minimally tilled (combination with chopped straw or other plant residues) and conventionally ploughed soil (Pabin et al., 2006; Mupangwa et al., 2007; Alletto et al., 2011; Wang et al., 2012). Comparison of no-till and mouldboard ploughing systems gave controversial results. In some experiments, no-tillage exhibited similar or higher maize yields than ploughing (Hussain et al., 1999; Carter et al., 2002; Tueche, Hauser, 2011; Xiaodong, Lijin, 2011; Wyngaard et al., 2012), in other no-till caused a decrease in maize productivity (Ojeniyi, Adekayode, 1999; Basamba et al., 2006; Tolimir et al., 2006; Messiga et al., 2012). Such results might have resulted from the differences in machinery, weed control efficacy (Culum, 2012), and increased soil compaction (Tolon-Becerra et al., 2011). Sometimes in no-tilled soil conditions grain yields were generally higher in dry years but lower in wet ones (Wang et al., 2011).

Our experiment hypothesizes that reduction of primary soil tillage from annual deep ploughing to shallow ploughing, chiselling or disking will not decrease maize productivity. No-tillage may lead to some decrease in maize yields.

\section{Materials and methods}

Site, soil and experiment description. A stationary long-term field experiment (since 1988, modified in 2000) was carried out at the Experimental Station of the Lithuanian University of Agriculture (currently Aleksandras Stulginskis University, ASU) (54 $52^{\prime} \mathrm{N}$, $23^{\circ} 49^{\prime} \mathrm{E}$ ). The data obtained during the 2010-2012 period are presented. The Lithuanian climate is transitional maritime-continental with wet winters and moderate summers. The highest average annual precipitation is on the coast of the Baltic Sea $(720 \mathrm{~mm})$ and the lowest - in the eastern part of the country $(490 \mathrm{~mm})$. The mean annual (last 59 years) precipitation rate in the experimental site is $625.5 \mathrm{~mm}$. The soil of the experimental site is silty light loam Endohypogleyic-Eutric Planosol (PLe-gln-w). The ploughlayer of this soil consisted of $45.6 \%$ sand, $41.7 \%$ silt, $12.7 \%$ clay and had moderate humus and high calcium content. Other soil chemical properties and their variation are presented in Table 1.

Table 1. Soil agrochemical properties ASU Experimental Station, 2010-2012

\begin{tabular}{|c|c|c|c|}
\hline Index & $\begin{array}{l}\text { Sampling } \\
\text { depth } \mathrm{cm}\end{array}$ & Values & Evaluation \\
\hline \multirow{2}{*}{$\mathrm{pH}_{\mathrm{KCl}}$} & $0-15$ & $6.64-7.04$ & $\begin{array}{l}\text { approximately } \\
\text { neutral }\end{array}$ \\
\hline & $15-25$ & $6.65-6.98$ & $\begin{array}{l}\text { approximately } \\
\text { neutral }\end{array}$ \\
\hline \multirow{2}{*}{$\mathrm{P}_{2} \mathrm{O}_{5} \mathrm{mg} \mathrm{kg}^{-1}$} & $0-15$ & $141.0-205.3$ & average-high \\
\hline & $15-25$ & $111.2-182.8$ & average-sufficient \\
\hline \multirow{2}{*}{$\mathrm{K}_{2} \mathrm{O} \mathrm{mg} \mathrm{kg}^{-1}$} & $0-15$ & $76.2-130.8$ & low-average \\
\hline & $15-25$ & $49.2-91.8$ & very low-low \\
\hline
\end{tabular}

The experimental treatments: 1) conventional (22-25 cm) ploughing by a mouldboard plough, 2) shallow $(12-15 \mathrm{~cm})$ ploughing by a mouldboard plough, 3) deep $(25-30 \mathrm{~cm})$ cultivation by a chisel cultivator, 4) shallow $(10-12 \mathrm{~cm})$ cultivation by a disc harrow, 5) notill. The number of replications was four, plot layout randomized, the initial size of each plot $-70 \mathrm{~m}^{2}$. Crop rotation: spring oilseed rape, winter wheat, maize, spring barley. Technological aspects of the experiment are presented in Table 2 . After winter wheat harvesting, stubble was shallowly disked (except for NT plots). In the beginning of September, no-tilled plots were sprayed with a herbicide Roundup (glyphosate $360 \mathrm{~g} \mathrm{l}^{-1}$ ), 41 ha $^{-1}$. In October, primary soil tillage was performed.

Table 2. Maize growing practices employed in the field experiment

ASU Experimental Station, 2010-2012

\begin{tabular}{|c|c|}
\hline Operation & Timing \\
\hline 1. Herbicide application (glyphosate $360 \mathrm{~g} \mathrm{l}^{-1}$ ) $41 \mathrm{ha}^{-1}$ in no-tilled plots only & September \\
\hline 2. Primary soil tillage & October \\
\hline 3. Complex fertilization NPK 16:16:16 (300 $\left.\mathrm{kg} \mathrm{ha}^{-1}\right)$ & April, before sowing \\
\hline 4. Pre-sowing soil tillage & April \\
\hline 5. Sowing & end of April - beginning of May \\
\hline 6. Herbicide application (foramsulfuron $22.5 \mathrm{~g} \mathrm{l}^{-1}$ ) $1.51 \mathrm{ha}^{1}$ & May, before 6-leaf development stage of maize \\
\hline 7. Additional fertilization with ammonium nitrate $\left(\mathrm{N}_{68}\right) 200 \mathrm{~kg} \mathrm{ha}^{-1}$ & end of May - beginning of June \\
\hline 9. Harvesting & end of September - beginning of October \\
\hline
\end{tabular}

In April, before pre-sowing soil tillage complex fertilizer NPK 16:16:16 (300 $\left.\mathrm{kg} \mathrm{ha}^{-1}\right)$ was applied. The soil of the plots was tilled by a complex cultivator at 5-6 cm depth before sowing. Maize hybrids of earlier maturity (FAO 180-200) were sown using a strip method by a cereal and rape sowing machine Väderstad Rapid 300C Super XL (Väderstad Ltd., Sweeden). The distance between rows in strip was $12.5 \mathrm{~cm}$, between strips $-50 \mathrm{~cm}$. Sowing rate -100 thousand seeds per ha (approximately 21-23 $\mathrm{kg} \mathrm{ha}^{-1}$ ). In May maize, the crop was sprayed with a herbicide Maister (foramsulfuron $22.5 \mathrm{~g} \mathrm{l}^{-1}$ ) $1.51 \mathrm{ha}^{1}$ and additionally fertilized with ammonium nitrate. Maize was harvested at the end of September - beginning of October (kernels contained about $60 \%$ of dry matter).

Methods. In 10 randomized places per each experimental plot, samples for the evaluation of maize crop density were taken 25 days from the beginning of seed germination and at the end of vegetation, for biometric and productivity parameters the samples were taken before harvesting. The total sampling area was 3.125 $\mathrm{m}^{2}$ per plot. The data of the experiment were analyzed by $A N O V A$. The treatment effect was tested by the $P$ test. The trial data were also evaluated using correlation and regression analysis by SigmaPlot software. 
Weather conditions. The weather conditions during maize vegetation are presented in Figure.

In 2010, maize vegetation season was characterized as mostly warmer and wetter than average of many years. The warmer were summer months. Vegetation of 2011 was semi humid in spring and too wet in summer time. Higher than usually temperatures were observed in April, June and July. Those conditions

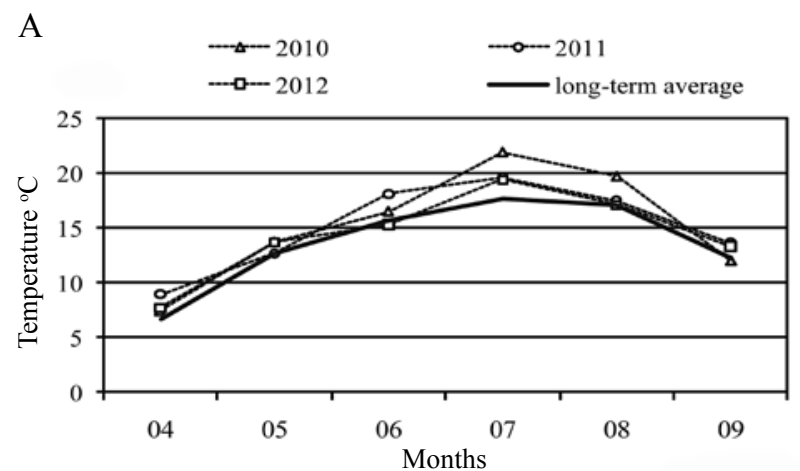

influenced the highest yields of maize grain and total biomass in the experiment. The humidity of 2012 was similar to that of 2010-2011; however, the temperatures nearly corresponded to average of many years. Yields were lower than in 2011; however, higher than in 2010.

Higher than usual precipitation rate during vegetation (May-September) of 2010-2012 influenced more active spread of weeds $(r=0.302-0.305)$.

B

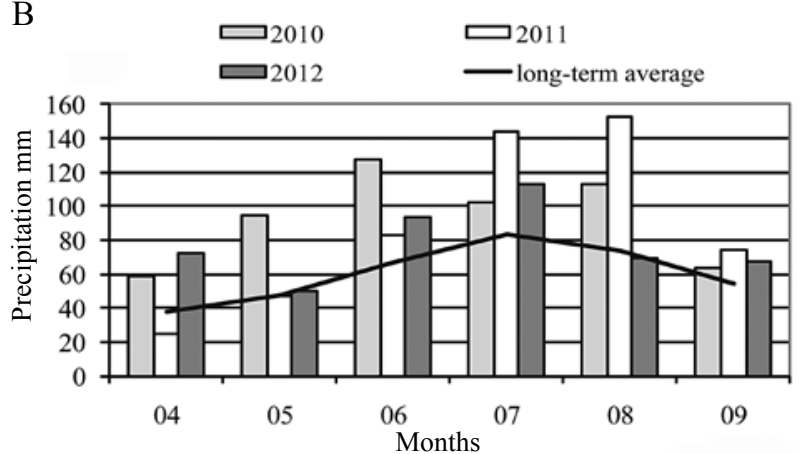

Figure. Average air temperature (A) and amount of precipitation (B) during maize vegetation Kaunas Meteorological Station, 2010-2012

\section{Results and discussion}

There was found a significant interaction between the conditions of experimental years and results of investigations. As a result, the mean data were not presented.

Maize biometric parameters. Different intensity of primary soil tillage influenced maize canopy height more than other biometric parameters (Table 3 ). The impact of soil tillage methods on average maize canopy height was not clear and mostly depended on the weediness of crop (Table 5). Deep soil tillage by a chisel cultivator up to $30 \mathrm{~cm}$ depth had stable significantly negative effect on the height of maize canopy. The reduced of soil tillage intensity from deep annual ploughing to disking consistently negatively influenced the height of maize canopy. Maize canopy grown in no-tilled soil was of similar height to that grown in deeply ploughed plots. In Karunatilake et al. (2000) experiment, no-till system recorded higher maize height than in mouldboard plough till or ridge till systems. Deep chiselling had negative influence on average cob length and number of kernels per row of cob, no-till - mostly positive. The impact of other tillage methods was normally insignificant.

Maize productivity parameters. In 2010 and 2012 , the density of maize crop at the beginning and the end of vegetation was even and similar in differently tilled plots (Table 4). Similarly, Carter et al. (2002) found, that plant population density was not consistently influenced by the tillage treatments (no-tilled and conventional mouldboard ploughing). In 2011, the variation of crop density increased. At the beginning of vegetation, the highest crop density was observed in deeply ploughed and no-tilled plots. A relationship was found between the number of annual as well as total weeds and crop density at the beginning of vegetation $\left(r=-0.926^{* *}\right.$ and $\left.-0.948^{* *}\right)$. At the end of vegetation, the highest crop density was estimated in chiselled plots and the lowest - in no-tilled. An increase in maize crop density at the
Table 3. Maize crop biometric parameters before harvesting

ASU Experimental Station, 2010-2012

\begin{tabular}{|c|c|c|c|}
\hline Soil tillage & $\begin{array}{c}\text { Canopy } \\
\text { height } \\
\mathrm{cm}\end{array}$ & $\begin{array}{c}\text { Cob } \\
\text { length } \\
\mathrm{cm}\end{array}$ & $\begin{array}{l}\text { Number } \\
\text { of kernels } \\
\text { per row } \\
\text { of cob }\end{array}$ \\
\hline \multicolumn{4}{|c|}{2010} \\
\hline Conventional ploughing & 202.2 & 12.0 & 22 \\
\hline Shallow ploughing & 200.8 & 11.1 & 20 \\
\hline Chiselling & $175.9 * *$ & $10.2 * *$ & 18 \\
\hline Disking & 194.6 & 11.6 & 22 \\
\hline No-till & 212.7 & $13.1 *$ & 26 \\
\hline \multicolumn{4}{|c|}{2011} \\
\hline Conventional ploughing & 304.3 & 14.8 & 30 \\
\hline Shallow ploughing & 300.5 & 14.8 & 29 \\
\hline Chiselling & $281.4 * *$ & 14.2 & 28 \\
\hline Disking & $284.4 * *$ & 14.8 & 30 \\
\hline No-till & 299.3 & 15.8 & 32 \\
\hline \multicolumn{4}{|c|}{2012} \\
\hline Conventional ploughing & 216.8 & 12.1 & 22 \\
\hline Shallow ploughing & $187.4^{*}$ & $10.4^{*}$ & 20 \\
\hline Chiselling & $167.2 * *$ & $8.3 * *$ & $17 * *$ \\
\hline Disking & $186.3^{*}$ & 10.8 & $18 * *$ \\
\hline No-till & 209.0 & 11.9 & 21 \\
\hline
\end{tabular}

* - significant differences from the control treatment (conventional ploughing) at $P \leq 0.05, * *-P \leq 0.01$

beginning of vegetation had significant positive effect on its productivity parameters (Table 6), and at the end of maize vegetation the effect was often insignificant $\left(r_{n s}\right)$.

Croatian scientists found the highest yield of maize in the conditions of chisel ploughing plus disc harrowing (Kovacev et al., 2010). In our experiment, deep soil chiselling in autumn decreased dry biomass of maize canopy, grain yield and 1000 kernel weight, except in 2011, when maize was grown in denser crop. Generally, in 2010-2011 reducing of soil tillage intensity often had insignificant and not inconsistent effect on 
maize productivity parameters. In 2010, the highest biomass of canopy, grain yield and 1000 kernel weight were established for maize crop grown in no-tilled soil. In Gul et al. (2009) zero tillage experiments, the biological yield was $7708 \mathrm{~kg} \mathrm{ha}^{-1}$ as compared to $7980 \mathrm{~kg} \mathrm{ha}^{-1}$ in conventional tillage. In our experiment, in 2011 reducing of soil tillage intensity from deep ploughing to disking had positive effect on the total amount of dry biomass and grain yield. In Bayhan et al. (2006) experiments, the lowest yield of maize silage was estimated for the plots under heavy-duty disc harrow tillage. In our experiment, no-till showed slightly worse results (in 2011-2012 only) than deep ploughing. In 2012, reduced soil tillage had significantly negative effect on maize biomass and grain yield. No-till decreased dry biomass of maize canopy and 1000 kernel weight, but this influence was insignificant. Such results were partially influenced by the spread of weeds (Table 5). In 2011, the number of weeds at the beginning of vegetation was by on average 250 weeds $\mathrm{m}^{-2}$ lower than that in 2010 , and at the end of vegetation by about 160 weeds $\mathrm{m}^{-2}$ lower than in 2012 . Thus reduced soil tillage had total positive effect on maize productivity in 2011 only. In 2010, deep soil chiselling promoted the spread of weeds (especially perennial species), which caused a dramatic decrease in maize productivity (data are not presented).

Soil chemical and physical properties had a greater impact on the growth of weeds than on maize crop.

Table 4. Maize crop productivity parameters

ASU Experimental Station, 2010-2012

\begin{tabular}{|c|c|c|c|c|c|c|c|}
\hline \multirow[t]{2}{*}{ Soil tillage } & \multicolumn{2}{|c|}{$\begin{array}{c}\text { Crop density } \\
\text { thousand plants } \mathrm{ha}^{-1}\end{array}$} & \multicolumn{3}{|c|}{ Dry biomass $\mathrm{tha}^{-1}$} & \multirow{2}{*}{$\begin{array}{c}\text { Grain yield } \\
\mathrm{tha}^{-1}\end{array}$} & \multirow{2}{*}{$\begin{array}{l}1000 \text { kernel } \\
\text { weight g }\end{array}$} \\
\hline & beginning & end & cobs & leaves and stems & total of canopy & & \\
\hline \multicolumn{8}{|c|}{2010} \\
\hline Conventional ploughing & 61.2 & 75.2 & 4.79 & 3.68 & 8.47 & 3.62 & 153.95 \\
\hline Shallow ploughing & 49.2 & 77.3 & 5.03 & 3.30 & 8.33 & 3.30 & 142.36 \\
\hline Chiselling & 47.2 & 77.2 & 3.95 & $2.43 * *$ & 6.38 & $2.10^{*}$ & $101.99 * *$ \\
\hline Disking & 55.2 & 70.8 & 4.79 & 3.29 & 8.08 & 3.53 & 144.77 \\
\hline No-till & 52.0 & 71.2 & $7.10 *$ & $4.30 *$ & $11.40 *$ & 4.68 & 165.76 \\
\hline \multicolumn{8}{|c|}{2011} \\
\hline Conventional ploughing & 93.2 & 65.6 & 13.12 & 8.16 & 21.28 & 11.22 & 252.03 \\
\hline Shallow ploughing & $84.8^{*}$ & 65.6 & 13.17 & 8.67 & 21.84 & 11.94 & 254.73 \\
\hline Chiselling & 85.6 & $85.6 * *$ & 13.70 & 9.55 & 23.25 & $12.98^{*}$ & 250.56 \\
\hline Disking & $83.6^{*}$ & 68.8 & $11.34 *$ & 11.17 & 22.51 & 11.70 & 247.38 \\
\hline No-till & 92.0 & 56.0 & 12.89 & 7.60 & 20.49 & 11.17 & $269.41 *$ \\
\hline \multicolumn{8}{|c|}{2012} \\
\hline Conventional ploughing & 94.8 & 70.0 & 9.75 & 6.25 & 16.00 & 8.20 & 224.30 \\
\hline Shallow ploughing & 84.4 & 68.0 & $7.40 * *$ & $4.40 * *$ & $11.80^{* *}$ & $6.14^{*}$ & 222.95 \\
\hline Chiselling & 91.2 & 70.4 & $6.87 * *$ & $3.69 * *$ & $10.56 * *$ & $5.69 *$ & 212.03 \\
\hline Disking & 88.0 & 66.8 & $7.50 * *$ & $3.90 * *$ & $11.40 * *$ & 6.39 & 222.44 \\
\hline No-till & 88.4 & 68.4 & 8.41 & 5.86 & 14.27 & $6.02 *$ & 209.55 \\
\hline
\end{tabular}

* - significant differences from the control treatment (conventional ploughing) at $P \leq 0.05, * *-P \leq 0.01$; grain moisture content $-15 \%$

Table 5. The relationship (simple correlation coefficient $r$ ) between weediness and maize crop biometric and productivity parameters

ASU Experimental Station, 2010-2012

\begin{tabular}{|c|c|c|c|c|c|c|c|c|}
\hline \multirow[b]{2}{*}{ Parameters $x$} & \multicolumn{3}{|c|}{ Biometric parameters $Y_{1}$} & \multicolumn{5}{|c|}{ Productivity parameters $Y_{2}$} \\
\hline & $\begin{array}{l}\text { Canopy } \\
\text { height } \\
\mathrm{cm}\end{array}$ & $\begin{array}{c}\text { Cob length } \\
\mathrm{cm}\end{array}$ & $\begin{array}{l}\text { Number of } \\
\text { kernels per } \\
\text { row of cob }\end{array}$ & $\begin{array}{c}\text { dry } \\
\text { biomass } \\
\text { of cobs } \\
\text { t ha }^{-1}\end{array}$ & $\begin{array}{c}\text { dry biomass of } \\
\text { leaves } \\
\text { and stems } \\
\mathrm{t} \mathrm{ha}^{-1}\end{array}$ & $\begin{array}{l}\text { total dry } \\
\text { biomass } \\
\text { of canopy } \\
\text { t ha }^{-1}\end{array}$ & $\begin{array}{c}\text { grain yield } \\
\mathrm{t} \mathrm{ha}^{-1}\end{array}$ & $\begin{array}{c}1000 \text { kernel } \\
\text { weight g }\end{array}$ \\
\hline AWB & $\mathrm{n}$ & $\mathrm{n}$ & $\mathrm{n}$ & -0.496 & -0.375 & -0.453 & -0.493 & $-0.772 * *$ \\
\hline PWB & $-0.652 * *$ & $-0.663 * *$ & $-0.685 * *$ & -0.394 & -0.454 & -0.430 & -0.360 & $\mathrm{n}$ \\
\hline TWB & -0.328 & -0.229 & -0.250 & $-0.610^{*}$ & -0.500 & $-0.574^{*}$ & $-0.599 *$ & $-0.835 * *$ \\
\hline AWE & $-0.723 * *$ & $-0.604 *$ & $-0.635^{*}$ & $-0.912 * *$ & $-0.835 * *$ & $-0.898 * *$ & $-0.919 * *$ & $-0.962 * *$ \\
\hline TWE & $-0.723 * *$ & $-0.591 *$ & $-0.620^{*}$ & $-0.909 * *$ & $-0.834 * *$ & $-0.896 * *$ & $-0.917 * *$ & $-0.965 * *$ \\
\hline
\end{tabular}

Notes. $*-P \leq 0.05, * *-P \leq 0.01, \mathrm{n}-$ low insignificant relation. AWB - number of annual weeds at the beginning of maize vegetation (variation 107.2-625.8 $\mathrm{m}^{-2}$ ), PWB - number of perennial weeds at the beginning of maize vegetation (variation 11.3$155.4 \mathrm{~m}^{-2}$ ), TWB - total number of weeds at the beginning of maize vegetation (variation 190.0-691.2 $\mathrm{m}^{-2}$ ), AWE - number of annual weeds at the end of maize vegetation (variation $6.7-467.9 \mathrm{~m}^{-2}$ ), TWE - total number of weeds at the end of maize vegetation (variation $47.5-483.3 \mathrm{~m}^{-2}$ ).

In our previous field experiment, maize canopy height was a key parameter, which strongly influenced cob length, number of kernels per row of a cob, dry biomass of canopy and grain yield (Romaneckas et al.,
2012). Similar relationships were established in the current experiment. Maize canopy height had higher relationship with productivity parameters than biometric indices (Table 6). 
Table 6. The relationship (simple correlation coefficient $r$ ) between maize crop biometric and productivity parameters ASU Experimental Station, 2010-2012

\begin{tabular}{|c|c|c|c|c|c|}
\hline \multirow[b]{2}{*}{ Biometric parameters $x$} & \multicolumn{5}{|c|}{ Productivity parameters $Y$} \\
\hline & $\begin{array}{c}\text { dry biomass } \\
\text { of cobs } \\
\mathrm{t} \mathrm{ha}^{-1}\end{array}$ & $\begin{array}{c}\text { dry biomass } \\
\text { of leaves and stems } \\
\mathrm{t} \mathrm{ha}^{-1}\end{array}$ & $\begin{array}{c}\text { total dry biomass } \\
\text { of canopy } \\
\mathrm{t} \mathrm{ha}^{-1}\end{array}$ & $\begin{array}{l}\text { grain yield } \\
\mathrm{t} \mathrm{ha}^{-1}\end{array}$ & $\begin{array}{l}1000 \text { kernel } \\
\text { weight g }\end{array}$ \\
\hline $\begin{array}{l}\text { Crop density at the beginning of } \\
\text { vegetation thousand plants } \text { ha }^{-1}\end{array}$ & $0.726 * *$ & $0.591 *$ & $0.682 * *$ & $0.725 * *$ & $0.904 * *$ \\
\hline Canopy height $\mathrm{cm}$ & $0.905 * *$ & $0.893 * *$ & $0.920 * *$ & $0.893 * *$ & $0.713 * *$ \\
\hline Cob length $\mathrm{cm}$ & $0.794 * *$ & $0.813 * *$ & $0.821 * *$ & $0.772 * *$ & $0.583^{*}$ \\
\hline Number of kernels per row of a cob & $0.816^{* *}$ & $0.832 * *$ & $0.842 * *$ & $0.802 * *$ & $0.621 *$ \\
\hline
\end{tabular}

$*-P<0.05, * *-P<0.01$

\section{Conclusions}

1. Different primary soil tillage methods (except for chiselling) normally had no significant effect on maize biometric parameters. Deep chiselling had a consistent negative influence on the biometric parameters of maize canopy, while the effect of no-till was insignificantly positive. Maize canopy height, cob length and number of kernels per cob row partially depended on the number of perennial weeds at the beginning of maize vegetation $\left(r=-0.652^{* *},-0.663 * *,-0.685^{* *}\right)$, number of annual weeds $\left(r=-0.723^{* *},-0.604^{*},-0.635^{*}\right)$ and total number of weeds $\left(r=-0.723^{* *},-0.591 *, 0.620^{*}\right)$ at the end of maize vegetation.

2. In two out of three experimental years, maize crop density at the beginning and end of vegetation was even and similar in differently tilled plots. A relationship was established between the number of annual as well as total number of weeds and crop density at the beginning of vegetation $\left(r=-0.926^{* *}\right.$ and $\left.-0.948^{* *}\right)$. Higher maize crop density at the beginning of vegetation had significant positive effect on dry biomass of cobs $(r=$ $\left.0.726^{* *}\right)$, dry biomass of leaves and stems $(r=0.591 *)$, total dry biomass of canopy $(r=0.682 * *)$, grain yield $\left(r=0.725^{* *}\right)$ and 1000 kernel weight $\left(r=0.904^{* *}\right)$. At the end of maize vegetation, crop density had a weak influence on the productivity parameters.

3. Reduced soil tillage from shallow ploughing to no-till had total positive effect on maize productivity in 2011 only because of the lower weed pressure. Relationships were estimated between weed infestation and maize crop productivity parameters (correlation coefficients from -0.394 to $-0.965^{* *}$ ).

4. There were found strong and significant relationships between maize canopy height and dry biomass of cobs, leaves and stems, total dry biomass of canopy, grain yield and 1000 kernel weight $\left(r=0.905^{* *}, 0.893 * *\right.$, $\left.0.920 * *, 0.893^{* *}, 0.713^{* *}\right)$. The relationships of other biometric parameters and maize productivity were weaker.

\section{Acknowledgements}

Investigations were partly funded by a grant (No. MIP-116/2012) from the Research Council of Lithuania. We also would like to thank Mrs. Vilma Pilipavičienè for some corrections of the English language in the paper.

Received 21022013

Accepted 23072013

\section{References}

Alletto L., Coquet Y., Justes E. 2011. Effect of tillage and fallow period management on soil physical behavior and maize development. Agricultural Water Management, 102: 74-85 http://dx.doi.org/10.1016/j.agwat.2011.10.008

Basamba T. A., Barrios E., Ame'zguita E., Rao I. M., Singh B. R. 2006. Tillage effects on maize yield in a Colombian savanna Oxisol: soil organic matter and P fractions. Soil and Tillage Research. 91: 131-142 http://dx.doi.org/10.1016/j.still.2005.11.010

Bayhan Y., Kayisoglu B., Gonulol E., Yalcin H., Sungur N. 2006. Possibilities of direct drilling and reduced tillage in second crop silage corn. Soil and Tillage Research, 88: 1-7 http://dx.doi.org/10.1016/j.still.2005.04.012

Carter M. R., Sanderson J. B., Ivany J. A., White R. P. 2002. Influence of rotation and tillage on forage maize productivity, weed species, and soil quality of a fine sandy loam in the cool-humid climate of Atlantic Canada. Soil and Tillage Research. 67: 85-98

http://dx.doi.org/10.1016/S0167-1987(02)00043-0

Cesevičius G., Feiza V., Feizienè D. 2005. The influence of reduced tillage methods and crop residues on soil physical properties and yield of spring barley. Vagos, 69 (22): 7-19 (in Lithuanian)

Cullum R. F. 2012. Influence of tillage on maize yield in soil with shallow fraginan. Soil and Tillage Research, 119: 1-6 http://dx.doi.org/10.1016/j.still.2011.11.011

Gaile Z. 2012. Maize (Zea mays L.) response to sowing timing under agro-climatic conditions of Latvia. ZemdirbysteAgriculture, 99 (1): 31-40

Gul B., Marwat K. B., Hassan G. 2009. Impact of tillage, plant population and mulches on biological yield of maize. Pakistan Journal of Botany, 41 (5): 2243-2249

Hao X., Chang C., Conner R. L., Bergen P. 2001. Effect of minimum tillage and crop sequence on crop yield and quality under irrigation in southern Alberta clay loam soil. Soil and Tillage Research. 59: 45-55 http://dx.doi.org/10.1016/S0167-1987(00)00185-9

Håkansson I., Stenberg M., Rydberg T. 1998. Long-term experiments with different depth of mouldboard ploughing in Sweden. Soil and Tillage Research. 46: 209-223 http://dx.doi.org/10.1016/S0167-1987(98)00099-3

Hussain I., Olson K. R., Ebelhar S. A. 1999. Impact of tillage and no-till on production of maize and soybean on an eroded Illinois silt loam soil. Soil and Tillage Research. 52: 37-49 http://dx.doi.org/10.1016/S0167-1987(99)00054-9

Karunatilake U., van Es H. M., Schindelbeck R. R. 2000. Soil and maize response to plow and no-tillage after alfalfa-tomaize conversion on clay loam soil in New York. Soil and Tillage Research. 55: 31-42 http://dx.doi.org/10.1016/S0167-1987(00)00096-9

Kovacev I., Kosutic S., Filipovic D., Pospisil M., Gospodaric Z. 2010. Maize and sunflower production in Pasavina, Croatia influenced by different soil tillage systems. Lucrări Ştiinţifice, seria Agronomie, 53 (1): 26-31

Maikštėnienė S., Šlepetienè A., Masilionytė L. 2007. The effect of mouldboard nouldbo and ploughless primary soil tillage on the properties of Endocalcari-Endohypogheyic Cambisol and on energetic efficiency of agrosystems. Zemdirbyste-Agriculture, 94 (1): 3-23 (in Lithuanian) 
Messiga A. J., Ziadi N., Morel C., Grant C., Tremblay G., Lamarre G., Parent L.-E. 2012. Long term impact of tillage practices and biennial $\mathrm{P}$ and $\mathrm{N}$ fertilization on maize and soybean yields and soil P status. Field Crops Research, 133: 10-22 http://dx.doi.org/10.1016/j.fcr.2012.03.009

Mupangwa W., Twomlow S., Walker S., Hove L. 2007. Effect of minimum tillage on maize (Zea mays L.) yield and water content of clay and sandy soils. Physics and Chemistry of the Earth. 32: 1127-1134 http://dx.doi.org/10.1016/j.pce.2007.07.030

Ojeniyi S. O., Adekayode F. O. 1999. Soil conditions and cowpea and maize yield produced by tillage methods in the rainforest zone of Nigeria. Soil and Tillage Research. 51: 161-164 http://dx.doi.org/10.1016/S0167-1987(99)00018-5

Pabin J., Lipiec J., Wlodek S., Biskupski A. 2006. Maize response to different straw management and tillage systems under cereal crop rotation. International Agrophysics, 20: 141-146

Romaneckas K. 2011. Soil tillage optimization for sugar-beet crop. Žemès ūkio mokslai, 18 (2): 83-93 (in Lithuanian)

Romaneckas K., Šarauskis E., Pilipavičius V., Adamavičienė A., Avižienytè 2010. D. Impact of primary soil tillage intensity on maize (Zea mays L.) seedbed formation and productivity parameters. Journal of Food, Agriculture and Environment, $8(3-4): 132-136$

Romaneckas K., Adamavičienė A., Pilipavičius V., Šarauskis E., Avižienytė D., Buragienè S. 2012. Interaction of maize and living mulch. Crop weediness and productivity. Zemdirbyste-Agriculture, 99 (1): 23-30

Statistics Lithuania. 2005. Statistics (pre-defined tables). $<$ http://www.stat.gov.lt/en/pages/view/?id=1446) $>$ [accessed $17012013]$

Tolimir M., Veskovic M., Komljenovic I., Djalovic I., Stipesevic B. 2006. Influences of soil tillage and fertilization on maize yield and weed infestation. Cereal Research
Communications. 34 (1): 323-326

http://dx.doi.org/10.1556/CRC.34.2006.1.81

Tolon-Becerra A., Tourn M., Botta G. F., Lastra-Bravo X. 2011. Effects of different tillage regimes on soil compaction, maize (Zea mays L.) seedling emergence and yields in the eastern Argentinean Pampas region. Soil and Tillage Research, 117: 184-190 http://dx.doi.org/10.1016/j.still.2011.10.003

Tueche J. R., Hauser S. 2011. Maize (Zea mays L.) yield and soil physical properties as affected by the previous plantain cropping systems, tillage and nitrogen application. Soil and Tillage Research. 115-116: 88-93 http://dx.doi.org/10.1016/j.still.2011.07.004

Wang X., Dai K., Zhang D., Zhang X., Wang Y., Zhao Q., Cai D., Hoogmoed W. B., Oenema O. 2011. Dryland maize yields and water use efficiency in response to tillage/crop stubble and nutrient management practices in China. Field Crop Research. 120: 47-57 http://dx.doi.org/10.1016/j.fcr.2010.08.010

Wang X., Wu H., Dai K., Zhang D., Feng Z., Wu X., Jin K., Cai D., Oenema O., Hoogmoed W. B. 2012. Tillage and crop residue effect on rained wheat and maize production in northern China. Field Crops Research, 132: 106-116 http://dx.doi.org/10.1016/j.fcr.2011.09.012

Wyngaard N., Echeverri'a H. E., Sainz Rozas H. R., Divito G. A. 2012. Fertilization and tillage effects on soil properties and maize yield in a Southern Pampas Aggiudoll. Soil and Tillage Research. 119: 22-30 http://dx.doi.org/10.1016/j.still.2011.12.002

Xiaodong Q., Lijin L. 2011. Soil properties and crop yields after 11 years of no tillage farming in wheat-maize cropping system in North China Plain. Soil and Tillage Research, 113: 48-54 http://dx.doi.org/10.1016/j.still.2011.01.005

ISSN 1392-3196 / e-ISSN 2335-8947

Zemdirbyste-Agriculture, vol. 100, No. 4 (2013), p. 377-382

DOI 10.13080/z-a.2013.100.048

\title{
Ilgalaikio supaprastinto pagrindinio žemės dirbimo poveikis paprastojo kukurūzo (Zea mays L.) produktyvumui
}

\author{
D. Avižienytė, K. Romaneckas, R. Pališkytė, V. Bogužas, V. Pilipavičius, E. Šarauskis, \\ A. Adamavičienè, E. Vaiciukevičius
}

Aleksandro Stulginskio universitetas, Lietuva

\section{Santrauka}

Ilgalaikis lauko eksperimentas atliekamas nuo $1988 \mathrm{~m}$. Aleksandro Stulginskio universiteto Bandymų stotyje (54 $\left.52^{\prime} \mathrm{N}, 23^{\circ} 49^{\prime} \mathrm{E}\right)$. Straipsnyje pateikti 2010-2012 m. tyrimų duomenys. Eksperimento dirvožemis - dulkiško lengvo priemolio giliau glejjiškas pasotintasis palvažemis (PLb-g4). Vietovès, kurioje atliktas eksperimentas, klimatas yra pereinamasis kontinentinis-jūrinis. Vidutinè metiné paros oro temperatūra yra $6.2^{\circ} \mathrm{C}$. Tyrimų tikslas - nustatyti supaprastinto pagrindinio (rudeninio) žemès dirbimo ịtaką paprastojo kukurūzo (Zea mays L.) produktyvumui. Eksperimento laukeliai buvo: 1) giliai $(22-25 \mathrm{~cm})$ suarti verstuviniu plūgu, 2) sekliai $(12-15 \mathrm{~cm})$ suarti verstuviniu plūgu, 3) giliai $(25-30 \mathrm{~cm})$ idirbti armens purentuvu-kultivatoriumi (čyzeliu), 4) sekliai $(10$ $12 \mathrm{~cm}$ ) įdirbti diskinèmis akěčiomis, 5) neįdirbti. Eksperimento rezultatai parodè, kad skirtingi pagrindinio žemės dirbimo būdai dažniausiai neturejo esminès ịtakos kukurūzų biometriniams rodikliams, išskyrus gilųji purenimą. Gilusis purenimas stabiliai neigiamai veikè kukurūzo augalo antžeminès dalies biometrinius rodiklius, o dirvos neịdirbimas (tiesioginė sèja) - dažniausiai neesmingai teigiamai. Kukurūzų biometriniai rodikliai iš dalies priklausẻ nuo kukurūzų pasėlio piktžolètumo vegetacijos pradžioje ir pabaigoje. Dvejus iš trejų tyrimų metų skirtingais būdais ídirbtoje dirvoje augusiu kukurūzu pasèlio tankumas vegetacijos pradžioje ir pabaigoje esmingai nesiskyrè. Nustatytas priklausomumas $\left(r=-0,926^{* *}\right.$ ir $\left.-0,948^{* *}\right)$ tarp trumpaamžių arba visų rūšių piktžolių skaičiaus ir kukurūzu pasèlio tankumo vegetacijos pradžioje. Pasèlio tankumo padidejjimas vegetacijos pradžioje esmingai teigiamai paveikè daugumą kukurūzų produktyvumo rodiklių.

Supaprastintai įdirbtuose ar neịdribtuose eksperimento laukeliuose tik $2011 \mathrm{~m}$. nustatytas didesnis kukurūzu produktyvumas, nes mažiau išplito piktžolès. Nustatytas priklausomumas tarp pasėlio piktžolètumo ir kukurūzu produktyvumo rodiklių (koreliacijos koeficientai nuo $-0,394$ iki $-0,965^{* *}$ ), taip pat tarp kukurūzų biometrinių ir produktyvumo rodiklių (koreliacijos koeficientai nuo $0,713 * *$ iki $0,920^{* *}$ ).

Reikšminiai žodžiai: biometriniai rodikliai, produktyvumas, Zea mays, žemės dirbimas. 